\title{
Comparison of Physical and Biochemical Properties Between Pure and Adulterated Blossom Honeys
}

\section{Saf ve Hileli Ballar Arasında Fiziksel ve Biyokimyasal Özelliklerin Karşılaştırılması}

\author{
Research Article \\ Sevgi Kolaylı', Oktay Yıldız², Havvanur Güney', Zehra Can ${ }^{3 *}$ \\ 'Karadeniz Technical University, Faculty of Sciences, Department of Chemistry, Trabzon, Turkey. \\ ${ }^{2}$ Karadeniz Technical University, Maçka Vocational School, Maçka, Trabzon, Turkey. \\ ${ }^{3}$ Giresun University, Şebinkarahisar Technical Sciences Vocational School, Giresun, Turkey.
}

\section{A B S TR AC T}

$\mathrm{T}$

he purpose of this study was to find new parameters permitting the identification of adulterated honeys. For this reason, different qualities of adulterated honeys were produced. Honey bee colonies fed with three different sugar syrups, high fructose corn syrup 55 (HFCS-55), sucrose syrup and invert sugar syrups at 3 L/day in one concentration $(1: 1.5 \mathrm{~g} / \mathrm{v})$ for 15 days. After harvest, some physico-chemical $\left({ }^{13} \mathrm{C} /{ }^{12} \mathrm{C}, \mathrm{C} 4 \%, \mathrm{pH}\right.$, moisture, optical rotation, electrical conductivity, sugar analyses, proline and diastase) and biological (total phenolic contents, phenolic profile, and antioxidant capacities) properties of the honeys were analyzed and compared. Conductivity, proline content, total phenolic content, diastase activities and antioxidant properties of the honeys were found distinguished parameters. Antioxidant capacity was significantly decreased in adulterated honeys.

\section{Key Words}

Pure honey, adulteration, physico-chemical parameters, antioxidant, phenolics.

\section{öz}

u çalışmanın amacı, sahte balların tanımlanması için yeni parametrelerin bulunmasıdır. Bu sebepden ötürü, farklı kalitede sahte ballar üretildi. Üç farklı şeker şurubu, yüksek fruktoz mısır şurubu 55 (HFCS-55), sukroz şurubu ve invert şeker şurubu 15 gün boyunca günde bir derişimde $(1: 1.5 \mathrm{~g} / \mathrm{v})$ günde $3 \mathrm{~L}$ olacak şekilde kolonilerde bal arıları beslendi. Hasat edildikten sonra, bazı fiziko-kimyasal $\left({ }^{13} \mathrm{C} /{ }^{12} \mathrm{C}, \% \mathrm{C} 4, \mathrm{pH}\right.$, nem, optik rotasyon, elektrik iletkenliği, şeker analizleri, prolin ve diastaz), biyolojik (toplam fenolik içeriği, fenolik profil ve antioksidan kapasiteleri) özellikleri ballarda karşılaştırılarak analiz edildi. Balların iletkenlik, prolin içeriği, toplam fenolik içeriği, diastaz aktiviteleri ve antioksidan özellikleri belirgin parametreler olarak bulundu. Antioksidan kapasiteleri sahte ballarda önemli ölçüde azalmıştır.

Anahtar Kelimeler

Saf bal, hileli, fiziko-kimyasal parametreler, antioksidan, fenolikler.

Article History: Received: Apr 22, 2017; Revised: May 09, 2017; Accepted: Sep 12, 2017; Available Online: Dec 25, 2017. DOI: 10.15671/HJBC.2018.196

Correspondence to: Z. Can, Giresun University, Şebinkarahisar Technical Sciences Vocational School, Giresun, Turkey. 


\section{INTRODUCTION}

Loney is a high-energy, nutritious natural product used by man for hundreds of years because of its therapeutic properties and for protection against diseases. The adverse effects on human health of various chemicals are encouraging people to turn toward what is traditional and natural. There has been a shift toward bee products and honey in particular. In addition to the fact that honey is very popular and has a high economic value, concerns over making even greater profits leads to the production of adulterated honeys [1,2]. Honey is a natural compound, nearly $95 \%$ of the dry weight of which consists of fructose and glucose [3].

Various enzymes, organic acids, phenolic compounds, amino acids and minerals in its composition represent honey's biologically active compounds, and these vary depending on the floral characteristics of the region where it is produced $[4,5]$. Classical honey parameters set out in honey codices are no longer sufficient to determine the purity of honey $[6,7]$. These parameters are also unable to establish the true quality of honey, in other words, its biologically active value. New methods are therefore being sought to reveal adulteration in honey. Since honey is a mixture it has become one of the most highly adulterated products. Various means of adulteration are employed in order to increase productivity in bee colonies. The most commonly employed method is feeding bees with sugar syrups. Substances such as sucrose, starch-based sugars and invert sugar syrups significantly enhance honey production in the hive. All honeys produced using sugar syrups are adulterated, but it is difficult to determine the exact type and amount of adulteration $[2,7,8]$. There has been a considerable recent increase in the number of studies aimed at revealing adulteration in honey. Adulteration is tested by determining carbon isotope $\left({ }^{d 13} \mathrm{C}\right)$ levels in honey using elemental analyzerisotope ratio mass spectrometer (EA-IRMS). However, this method is more appropriate for some types of sugar and is not recommended for beet sugars and corn sugars [1,2].

\section{MATERIALS and METHODS}

\section{Chemicals}

2,4,6-tripyridyl-s-triazine (TPTZ), FolinCiocalteu's phenol reagent, 2, 2-diphenyl-1picrylhydrazyl (DPPH), Trolox® (6-hydroxy2,5,7,8-tetramethylchroman-2-carboxylic acid), were purchased from Sigma Chemical Co. (St Louis, MO, USA).

All chemical standards were HPLC-grade pure. The common phenolic compounds (gallic, protocatechuic acid, $p-\mathrm{OH}$ benzoic acid, catechin, vanillic acid, caffeic acid, $p$-coumaric acid, ferulic acid, rutin, $t$-cinnamic acid, luteolin) and sugars (ribose, arabinose, fructose, glucose, galactose, maltose, trehalose, melibiose, melezitose) were obtained from Sigma-Aldrich (Munich, Germany). Of the HPLC grade organic reagents, acetonitrile was supplied by Sigma-Aldrich Co. (St. Louis, MO, USA) and methanol was by Merck KGaA, Darmstandt, Germany). HPLC syringe filters (RCmembrane, $0.45 \mu \mathrm{m}$ ) were obtained from Sartorius Minisart RC 15, Sartorius (Germany).

\section{HoneySamples}

The characteristics of the sugar syrups used in the study and the firms from which they were purchased are summarized in Table1. This study involved four different hive groups, each of the groups containing eight hive colonies, for each honey group. The hives were located in the same area at distances of $50 \mathrm{~m}$ apart. The study was performed in 2015 in the province of Erzurum in Turkey's East Anatolia region, in the honey season, June-July. The lower levels of the hives were left empty, and hives were given a single daily 3 $\mathrm{L}$ /day concentration of sugar syrup over 15 days. A sucrose syrup mixture of 1:1.5 ( $\mathrm{g} / \mathrm{g}$ ) was prepared by us on a daily basis. Colonies were fed with direct high fructose corn syrups and high invert sugar syrups, they were supplied from Companies. Combs were removed from the hive and brought to the laboratory for investigation.

\section{Analytical Determinations}

$\mathrm{d}^{13} \mathrm{C}$ isotope analyses of the pure and the adulterated honeys were performed once the specimen had been completely carbondioxized using 
Table 1. Composition of sugar syrups used in the experiment.

\begin{tabular}{|c|c|c|c|}
\hline Honey & Sugar type & Origin & Composition \\
\hline 1 & $\begin{array}{l}\text { High Fructose Corn Syrups } \\
\text { (HFCS-55) }\end{array}$ & Zea mays & $\begin{array}{l}\text { Fructose } 55 \% \text {, Dextrose } \\
55 \%\end{array}$ \\
\hline 2 & Sucrose Syrup (SS) & Beet sugar & Sucrose $99.5 \%$ \\
\hline 3 & Invert sugar syrups (ISS) & Beet sugar & $\begin{array}{c}\text { Fructose } 39 \% \text {, Sucrose } \\
33 \% \text {, Glucose } 28 \%\end{array}$ \\
\hline
\end{tabular}

elemental analysis-isotope ratio mass spectrometry (EA-IRMS) [9]. C4\% sugar analysis in honey was calculated from the difference between $\mathrm{d}^{13}$ $\mathrm{C}$ isotopes in protein and honey as shown below $[1,2,10]$.

$\mathrm{C} 4 \%=\delta^{13} C_{\text {protein }}-\delta^{13} C_{\text {honey }} / \delta^{13} C_{\text {protein }}-(-9.7)$

Color value was measured using a Hunter spectrometer (CR-400, Minolta, Osaka, Japan), moisture using a refractometer (Atago, Tokyo, Japan), electrical conductivities using a conductometer (WTW inoLab Cond/720, Germany) and optical activity or rotation using a polarimeter (Beta PPP7 England). The physical characteristics of the honeys were in agreement with EU legislation [11].

Sugar analysis of the samples was performed using a refractive detector (RID) with HPLC (Elite LaChrom, Hitachi, Japan) using nucleosil column (200/4.6 Nucleosil 100-5 $\mathrm{NH}_{2}$ ). All standards of sugars and honey samples were dissolved with deionized water and filtered with HPLC syringe filters $(0.45 \mu \mathrm{m})$. The calibration curve of the sugars was calculated using five different concentrations of the standards (from 1.25 to $20 \mathrm{mg} / \mathrm{mL}$ ). Calibration curves were determined at between 0.994 and 1.000. Seventy-nine percent acetonitrile and $21 \%$ water were used as mobile phase in programmed isocratic elution. Injection of the sample volume was $25 \mathrm{~mL}$, column temperature $30^{\circ} \mathrm{C}$ and flow rate $1.5 \mathrm{~mL} / \mathrm{min}$. [3].

Proline content was measured using spectrometric assay [12]. Diastase activity was determined following the spectrophotometric method using a buffered solution of soluble starch and honey incubated in a thermostatic bath at $40^{\circ} \mathrm{C}$ [6]. Diastase units were expressed as 1\% starch hydrolyzed by an enzyme in $1 \mathrm{~g}$ of honey in $1 \mathrm{~h}$.

\section{Honey Extraction for Biological Activities Tests}

Methanolic extracts of the honeys were used for antioxidant analyses. Briefly, a $15 \mathrm{~g}$ sample of honey was placed in a falcon tube $(50 \mathrm{~mL})$, and 50 $\mathrm{mL}$ 99\% methanol was added. The mixture was continuously shaken with a shaker (HeidolphPromax 2020, Schwabach, Germany) at room temperature for $24 \mathrm{~h}$. The extract was filtered to remove particles using Whatson filter paper and then concentrated in a rotary evaporator (IKA-Werke, Staufen-Germany) under reduced pressure at $40^{\circ} \mathrm{C}$. The residue was divided into two parts. The first part was dissolved in methanol and used for antioxidant tests, and the second was used for phenolic analysis in HPLC.

\section{Extraction Procedure for Phenolic Analysis}

The second methanolic residue was dissolved in $10 \mathrm{~mL}$ distilled water at $\mathrm{pH} 2$ and stirred (HeidoIph shaker ProMax 2020, GmbHCo, KG) for $1 \mathrm{~h}$. The mixture was extracted with $3 \mathrm{~mL}$ of diethyl ether at least three times, stirred for 15 min and then shaken. The upper phase was placed into a $50 \mathrm{~mL}$ flask and extracted three times with $3 \mathrm{~mL}$ of ethyl acetate for $15 \mathrm{~min}$. [13]. The upper phase, consisting of organic solvent, was evaporated in a rotary evaporator under reduced pressure at $40^{\circ} \mathrm{C}$. The residue was weighed and dissolved in methanol for HPLC analysis for identification of phenolic compounds.

\section{Analysis of Phenolic Compounds by HPLC}

HPLC analyses of phenolic profiles were carried out on Elite LaChrom Hitachi, Japan HPLC with UV-Vis detector. C18 column $(150 \mathrm{~mm} \times 4.6 \mathrm{~mm}$, $5 \mu \mathrm{m}$; Fortis) was used. Gradient elution was used for HPLC analyses modifying the method developed by De Villiers [14]. The mobile phase consisted of (A) $2 \%$ acetic acid in water and (B) acetonitrile: 
water (70:30). The samples injection volume was $25 \mu \mathrm{L}$, column temperature at $30^{\circ} \mathrm{C}$ and flow rate at $0.75 \mathrm{~mL} / \mathrm{min}$. The fourteen standards were recorded at $280 \mathrm{~nm}$. The programmed solvent used began with a linear gradient held at $95 \% \mathrm{~A}$ for three minutes, decreasing to $80 \% \mathrm{~A}$ at $10 \mathrm{~min}$, $60 \% \mathrm{~A}$ at $20 \mathrm{~min}, 20 \% \mathrm{~A}$ at $30 \mathrm{~min}$ and finally 95\% A at 50 min. [3].

\section{Determination of Total Phenolic Content (TPC)}

Total phenolic contents of the methanolic extracts were determined following the Folin-Ciocalteu method using gallic acid as standard [15]. The Folin assay based on all phenolic contents including phenolic acids, flavonoids, and anthocyanins in an aquatic solution gives a blue color complex whose maximum absorbance can be read at 760 $\mathrm{nm}$. Briefly, $680 \mu \mathrm{L}$ distilled water, $20 \mu \mathrm{L}$ methanolic honey extracts and $400 \mu \mathrm{L}$ of $0.5 \mathrm{~N}$ FolinCiocalteu regents were mixed in a tube and vortexed for 2 min. Next, $400 \mu \mathrm{L} \mathrm{Na}_{2} \mathrm{CO}_{3}$ (10\%) was added and incubated for $2 \mathrm{~h}$ at room temperature. The absorbance was measured at $760 \mathrm{~nm}$ at the end of the incubation period. All measurements were performed in triplicate. TPC was expressed as $\mathrm{mg}$ of gallic acid equivalents per $100 \mathrm{~g}$ honey samples.

\section{Determination of Total Antioxidant Capacity}

The reducing ability of ferric tripyridyltriazine (Fe-III-TPTZ) complex was used for total antioxidant capacity assay [16]. Working FRAP reagent was prepared as required by mixing $25 \mathrm{~mL}$ of $300 \mathrm{mM}$ acetate buffer, $\mathrm{pH} 3.6$, with $2.5 \mathrm{~mL}$ of 10 $\mathrm{mM}$ TPTZ solution in $40 \mathrm{mMHCl}$ and $2.5 \mathrm{~mL} 20$ $\mathrm{mM} \mathrm{FeCl} 3 \cdot 6 \mathrm{H}_{2} \mathrm{O}$ solution. Next, $3 \mathrm{~mL}$ freshly prepared FRAP reagent and $100 \mu \mathrm{L}$ of the samples was mixed and incubated in $4 \mathrm{~min}$ at $37^{\circ} \mathrm{C}$ and the absorbance was read at $593 \mathrm{~nm}$ against reagent blank containing distilled water. Trolox was used a positive control to construct a reference curve $(62.5-1000 \mu \mathrm{M})$, FRAP values were expressed as $\mu \mathrm{M}$ Trolox equivalent of $\mathrm{g}$.

\section{Determination of Free Radial Scavenging Activity}

The scavenging of 2,2-diphenyl-1-picrylhydrazyl (DPPH) radicals was used to determine the radical scavenging activity of the methanolic honey samples. The colorimetric test was assayed us- ing the Molyneux method [17]. DPPH radical has a purple color which decays in the presence of antioxidant agents. The change in absorbance is monitored at $517 \mathrm{~nm}$. For each sample, $0.75 \mathrm{~mL}$ of methanol extract solution was mixed with $0.75 \mathrm{~mL}$ of $0.1 \mathrm{mM}$ DPPH (dissolved in methanol), vortexed and incubated for 50 min in the dark at room temperature. The blank contained DPPH solution with no sample. The results were expressed as $\mathrm{SC}_{50}$ $(\mathrm{mg} / \mathrm{mL})$, which was calculated from the curves by plotting absorbance values, with the $\mathrm{SC}_{50}$ values representing the concentration of extract (mg/ $\mathrm{mL}$ ) required to inhibit $50 \%$ of the radicals.

\section{RESULTS and DISCUSSION}

The value of $d^{13} \mathrm{C}$ of the pure honeys and the adulterated honeys with sugar syrupare summarized in Table 2. This method is based on the ${ }^{13} \mathrm{C} /{ }^{12} \mathrm{C}$ ratio of carbon atoms inside $\mathrm{CO}$ gas resulting from total combustion of pure honey and protein solution obtained from that honey, using a mass spectrometer. The percentage C4 sugar level is calculated from that value. $d^{13} \mathrm{C} \%$ isotope values of the pure honey and the adulterated honey were found below -25.00. According to the Honey Codes [6] the difference of $\delta^{13} \mathrm{C}$ between protein and raw honey must be -1 or more positive in blossom honeys and the level of $\mathrm{C} 4$ sugars calculated from the values $\delta^{13} \mathrm{C}$ of protein and raw honey must not exceed $7 \%$.

This analytical technique especially used to identify adulteration in honeys produced by the external addition of $\mathrm{C} 4$ sugars or obtained from bees fed on $\mathrm{C} 4$ sugar. $\delta^{13}$ Canalysis is an isotopic technique relies on differences in isotope levels between $\mathrm{C} 3$ and $\mathrm{C} 4$, naturally present in plants due to photosynthesis $[1,2,6,18]$ White and Anklam [5] reported limits for adulterated honeys (corn or sugar cane) of $21.5 \%$ and $23.5 \%$. According to $\mathrm{Pa}-$ dovanet al. (2007), the ${ }^{13} \mathrm{C} /{ }^{12} \mathrm{C}$ ratio or $\delta^{13} \mathrm{C}$ honey values in the $\mathrm{C} 3$ cycle range between $-22 \%$ and $-33 \%$, while those in the $\mathrm{C} 4$ cycle range between $10 \%$ and $20 \%$. In agreement with the findings in our study, another study reported that this isotope determination technique is insufficient to reveal adulteration in honeys performed with sugar beet $[1,2]$.

The physical characteristics of the honeys are summarized in Table 2. $\mathrm{pH}$ values of the honey 
Table 2. Physical and chemical properties of honey samples.

\begin{tabular}{|c|c|c|c|c|}
\hline Samples & PureHoney & HFCS-55 & Sucrose Syrup & Invert Sugar Syrup \\
\hline \multicolumn{5}{|c|}{ Physical Parameters } \\
\hline$\delta^{13} C_{\text {bal }}(\%)$ & -25.49 & -25.27 & -25.43 & -25.17 \\
\hline$\delta^{12} C_{\text {protein }}(\%)$ & -25.26 & -25.40 & -25.77 & -23.93 \\
\hline$\Delta \delta^{13} \mathrm{C}$ (protein-honey) & 0.23 & -0.13 & -0.34 & 1.24 \\
\hline C4 (\%) & -1.48 & 0.83 & 2.12 & -8.71 \\
\hline $\mathrm{pH}$ & $3.82 \pm 001$ & $4.05 \pm 0.02$ & $3.86 \pm 0.01$ & $3.95 \pm 0.03$ \\
\hline Moisture(\%) & $16.6 \pm 0.20^{a}$ & $15.4 \pm 0.25^{\mathrm{a}}$ & $16.8 \pm 0.18^{a}$ & $15.6 \pm 0.30^{a}$ \\
\hline $\operatorname{Ash}(\%)$ & $0.12 \pm 0.03^{a}$ & $0.03 \pm 0.01^{\mathrm{b}}$ & $0.08 \pm 0.02^{c}$ & $0.07 \pm 0.02^{c}$ \\
\hline $\begin{array}{l}\text { Conductivity (mS/ } \\
\mathrm{cm})\end{array}$ & $0.29 \pm 0.01^{\mathrm{a}}$ & $0.15 \pm 0.01^{b}$ & $0.20 \pm 0.01^{\mathrm{a}}$ & $0.16 \pm 0.00^{\mathrm{b}}$ \\
\hline Optic rotation & $-2.03 \pm 0.07^{a}$ & $0.61 \pm 0.02^{b}$ & $1.52 \pm 0.03^{c}$ & $1.00 \pm 0.02^{d}$ \\
\hline \multirow{3}{*}{ Colour } & $54.53 \pm 5.20^{\mathrm{a}}$ & $66.95 \pm 3.50^{b}$ & $86.65 \pm 6.21^{c}$ & $68.98 \pm 2.05^{d}$ \\
\hline & $1.65 \pm 0.50^{a}$ & $4.27 \pm 0.62^{b}$ & $5.53 \pm 0.39^{c}$ & $8.82 \pm 0.72^{d}$ \\
\hline & $31.56 \pm 2.10^{\mathrm{a}}$ & $14.99 \pm 3.00^{b}$ & $13.15 \pm 1.56^{b}$ & $24.27 \pm 3.60^{c}$ \\
\hline
\end{tabular}

Means \pm standard deviations;Different letters (a-d) in the same lines are significantly different at the $5 \%$ level $(p<0.05)$.

samples ranged from 3.82 to 4.05 . No significant difference was determined between the $\mathrm{pH}$ of pure and adulterated honeys in this study. Due to the presence of the various amino acids and organic acids contained in honey, its $\mathrm{pH}$ value is generally shows acidic character, between 3.5 and $4.5[5,11,19]$. Gluconic acid at a major level in honey samples, and succinic, citric, malic, formic, oxalic and butyric acids, were present a minor levels. Amino acid of proline is present in high amount and but other nineteens are also lower in honey. Due to their weak acidic and weak bacis characteristics, both organic acids and amino acids provide honey buffering at acidic $\mathrm{pH}[5,20]$. Honeys' moisture values ranged between 15.4 and 16.8 , and the differences were not significant. The moisture content of both the pure and adulterated honeys being below $20 \%$ reveals compatibility with the honey codices. The moisture content of honey depends mostly on the type of production associated with degree of maturity, and to a lesser extent on flora and climatic conditions [5,21-23]. Honeys harvested before full maturation have high moisture content, leading to honey fermentation. Some yeasts (osmophilic yeasts) are able to remain alive in honeys containing a high moisture level, and these cause the honey to spoil. In contrast, the moisture content of mature honey is too low to permit any micro-organism to develop [7].

The total ash content of pure and adulterated honeys ranged between $0.03 \%$ and $0.12 \%$ Table 2 . The pure honey had the highest ash content, while the adulterated honey produced with HFCS had the lowest level. Similar levels were detected in honeys involving feeding with sucrose and invert sugars. Honey's ash content varies in accordance with the flora used by the bees $[24,25]$. However, honeys with a high mineral content have also been reported to contain a high percentage of ash. In addition, a positive correlation has been reported between the ash or mineral content of honey and its color, and dark honeys are generally reported to have higher ash contents $[8,21,22]$. Dark-colored honeys with high ash contents are generally reported to taste bitter $[2,20]$. Ash levels of between $0.02 \%$ and $0.18 \%$ have been reported in Argentinean honeys [24] and of between $0.02 \%$ and $0.28 \%$ in floral honeys [21]. The values from our study are compatible with those in the literature and the honey food codex $[21,24,25]$. 
Electrical conductivity, another of the physical characteristics of honey, ranged between 0.15 $\mathrm{mS} / \mathrm{cm}$ and $0.29 \mathrm{mS} / \mathrm{cm}$ Table 2 . The pure honey had greater conductivity than the adulterated honeys $(p<0.05)$. The honeys adulterated with sucrose syrup had higher conductivity than the two other adulterated honeys. The conductivity of honey is directly proportional to its mineral level and associated ash content. A positive correlation was determined between honey's ash levels and conductivity $\left(R^{2}: 0.86, p<0.05\right)$. One study involving Portuguese organic honeys reported that electrical conductivity varied between $0.09 \mathrm{mS} /$ $\mathrm{cm}$ and $0.43 \mathrm{mS} / \mathrm{cm}$, with a mean conductivity value of $0.26 \mathrm{mS} / \mathrm{cm}$ [26]. Electrical conductivity between $0.414 \mathrm{mS} / \mathrm{cm}$ and $1.748 \mathrm{mS} / \mathrm{cm}$ has been reported in pine honeys [27]. On the basis of the values obtained in this study, conductivity is not a sufficient parameter in the detection of adulterated honeys.

Honeys' optical rotation angles range between -2.03 and 0.61. In this study, the pure honeys and those obtained from bees fed on sucrose syrup and invert sugar syrup had a negative angle of optical rotation, while honey from bees fed with HFCS sugar syrup and a positive angle (Table 2 ). Blossom honeys generally have negative optical rotation (or levorotatory) values while honeydew honeys have positive (or dextrorotatory) rotation values. This property has been used to distinguish honeydew honeys and adulterated honeys $[8,28$, 29]. Although a positive optical rotation angle is a distinguishing parameter for honeydew honeys, it is interesting that the adulterated honey with HFCS syrup also had positive values. The positive rotation in blossom honeys may be regarded as an important parameter revealing adulteration. However, this applies to HFCS sugar syrups, while sucrose and invert sugar syrup have negative values. Therefore, while optical rotation value is an important factor showing adulteration, but the finding is not sufficient to confirm adulteration.

Honeys' color values were determined as Hunter $L^{*} a^{*} b^{*}$, and the values are shown in Table 2 [6]. Tritium color values for honeys were expressed as $L^{*}$ for darkness/lightness (0 black, 100 white), a* (-a greenness, + aredness), and $b *(-b$ blueness, $+b$ yellowness). Honey's L values ranged from L 54.53 to 86.65 , with a low $L$ value expressing darkness. The darkest honey was the pure honey, while the color was lighter in the adulterated honeys. The lightest-color was obtained in the sucrose syrup adulterated honey. In the same way as $L$ values, the adulterated honey's a and $b$ values also differ from those of the pure honey. Honey color is an important physical parameter and varies depending on the flora involved and on associated vitamin, pigment, phenolic substance and mineral contents. Chlorophyll, carotene and xanthophyll's type compounds bestow a yellow-green color [20]. In addition, Maillard products emerging with exposure to heat treatment also cause honey to darken. Since the colors of the honeys studied were measured immediately without exposure to heat treatment Maillard reaction products are not thought to affect color [25].

One study employing the same color measurement techniques in floral honeys reported $L^{*}$ values between 43.02 and $81.21, a^{*}$ values between 2.91 and 63.40 and $b^{*}$ values between 25.44 and 43.47 [30]. Slovenian honeys have been reported to exhibit $L^{*}$ values between 42.12 and $64.60, a^{*}$ values between -3.41 and 10.14 and $b^{*}$ values between 17.95 and 4.45 [31]. The values from this study for the pure honey are in agreement with those in the literature, but color parameters singly cannot be used to determine honey adulteration.

In the Table 2 are given the varying proline, diastase activity and sugar parameters in the studied honeys. Proline levels were showed widely ranged, between $269.79 \mathrm{mg} / \mathrm{kg}$ and 1132.45 $\mathrm{mg} / \mathrm{kg}$. The highest proline value was determined in the pure honey and the lowest in the adulterated honey with different sugar syrups. Although honey contains all amino acids, proline is interestingly present in the highest quantities. While proline level is a marker of honey purity, it also reflects the work performance of the bees [32]. Experimental studies have reported that honeys produced by bees fed on sugar syrup contain low levels of proline [8]. According to the European honey index, the amount of proline that should be present is below $150 \mathrm{mg} / \mathrm{kg}$ in honey, but the value is $300 \mathrm{mg} / \mathrm{kg}$ according to the Turkish Honey Codex (TSE). The level in quality honeys, however, is very much higher, and the honey codices are in 
need of revision [6]. Proline values in the honeys produced by bees fed on sugar syrups were below $300 \mathrm{mg} / \mathrm{kg}$, and also the proline levels in the honeys codices should be revised.

Diastase activities of the honey samples were also showed a widely ranged between 7.3 and 20.4. The pure honey also had the highest diastase activity, and HFCS sugar syrup and invert sugar syrup was the lowest. Diastase is a digestive enzyme that performs starch hydrolysis and is responsible for the freshness and quality of honey. A level below $8 \mathrm{DU}$ is undesirable in honey codices TSE [6]. Diastase activity in honeys decreases over time or with exposure to heat treatment. Low diastase activity in these honeys, not exposed to any heat treatment, being low in HFSC and invert sugar syrup honeys indicates adulteration. These data indicate that diastase activity can be a differentiating marker in adulterated honeys made with sugar syrups, with the exception of sucrose syrup.

Honeys' fructose, glucose and sucrose contents were determined using HPLC-RID. Sucrose contents of the pure honeys and those adulterated with sugar syrups were below $5 \%$, in line with the honey codex, the lowest sucrose content being in the pure honey TSE, [6]. Honey obtained from bees fed on sucrose syrup was expected to exhibit the highest sucrose level, but that was actually determined at $1.56 \%$. The main reason for this is inversion of sucrose, a honeybee digestive enzyme, by invertase into fructose and glucose. A large part of the sucrose syrup collected by bees undergoes inversion by invertase. One study reported sucrose levels of $1.23 \%$ in adulterated honey, similar to our findings [8]. Honeys' fructose and glucose levels do not differ from those of floral honeys [19]. Sucrose values of the honeys produced by bees fed with sucrose syrup once a day being compatible with the honey codex shows the difficulty in determining adulteration in honey.

More important than physical and chemical properties, adulteration affects honey's biologically active value. This study investigated how adulteration affected the biologically active compounds and antioxidant properties of honey. Ta- ble 3 shows the antioxidant activities associated with total polyphenol contents in the four different quality honeys studied. Honeys' total phenolic contents ranged between 6.13 and 98.00 $\mathrm{mg}$ GAE/100 g. The pure honey had the highest phenolic content, followed by honeys made with sucrose syrup, invert syrup and HFCS syrup. Although the total phenolic contents of honeys produced by bees fed on invert and sucrose syrups were lower than those of pure honey, they were higher than those of many pure honeys in the literature $[20,23]$. This shows that while being fed on sugar syrup, bees also bring nectar and pollen into the hive from outside. Total phenolic contents show that when bees were fed with HFCS nectar, transportation from outside was reduced to a minimum, while they did not completely cease bringing in pollen and nectar in the other sugar groups.

Honeys' antioxidant capacities were assayed using two different tests apart from total phenolic content. Both antioxidant techniques (FRAP and DPPH) are based on electron transfer and are the most commonly used methods of determining antioxidant capacity $[22,20,4]$. Honeys' FRAP values ranged between 105 and $285 \mu$ molTrolox/100 $\mathrm{g}$ (Table3). In this method, a high FRAP value indicates high antioxidant capacity, and the antioxidant capacity of the pure honey was approximately 2.5 times greater than that of the other honeys adulterated with sugar syrups. The FRAP values of the adulterated honeys with sucrose syrup was lower than that of the pure honeys but also the values were higher than those of the other two groups. One study reported the highest FRAP values in forest honey at $498 \mu \mathrm{molTE} / 100 \mathrm{~g}$, and values of $405 \mu \mathrm{molTE} / 100 \mathrm{~g}$ in honeydew honey, $67 \mu \mathrm{molTE} / 100 \mathrm{~g}$ in wild flowers honey, 61 $\mu \mathrm{molTE} / 100 \mathrm{~g}$ in linden honey, $26 \mu \mathrm{molTE} / 100 \mathrm{~g}$ in acacia honey and $4.00 \mu \mathrm{molTE} / 100 \mathrm{~g}$ in adulterated honey [33]. Another study of blossom and adulterated honeys reported FRAP values ranged from $27.0 \mu \mathrm{molTE} / 100 \mathrm{~g}$ to $96.6 \mu \mathrm{molTE} / 100 \mathrm{~g}$, but was measured $6.1 \mu \mathrm{molTE} / 100 \mathrm{~g}$ in false honey [34]. The results are proved that adulteration with some sugar syrups increase antioxidant capacity of honey. 
Table 3. Antioxidant parameters and phenolic compounds of honey samples.

\begin{tabular}{|c|c|c|c|c|}
\hline Samples & Pure Honey & HFCS-55 & Sucrose Syrup & Invert Sugar Syrup \\
\hline \multicolumn{5}{|c|}{ Antioxidant Parameters* } \\
\hline $\begin{array}{l}\text { Total Polyphenol } \\
\text { (mg GA/100 g) }\end{array}$ & $98.00 \pm 2.00^{a}$ & $6.13 \pm 0.30^{b}$ & $53.30 \pm 3.00^{c}$ & $34.60 \pm 1.00^{d}$ \\
\hline $\begin{array}{c}\text { FRAP } \\
(\mu \mathrm{molTrolox} / 100 \mathrm{~g})\end{array}$ & $284.10 \pm 18.00^{a}$ & $105.00 \pm 15.20^{b}$ & $183.70 \pm 8.10^{c}$ & $106.40 \pm 12.00^{b}$ \\
\hline $\begin{array}{l}\text { DPPH SC50 (mg/ } \\
\mathrm{mL})\end{array}$ & $13.70 \pm 0.11^{\mathrm{a}}$ & $82.36 \pm 0.70^{b}$ & $33.63 \pm 0.12^{c}$ & $64.57 \pm 0.43^{d}$ \\
\hline \multicolumn{5}{|c|}{ Phenolic Contents ( $\mu \mathrm{g}$ phenolics/g honey sample)* } \\
\hline Gallicacid & 1.84 & 1.20 & 0.91 & 0.82 \\
\hline Protocatechuic acid & $\mathrm{Nd}$ & 0.52 & n.d & 0.52 \\
\hline$p$-OH benzoic acid & 0.68 & 0.53 & n.d & 0.50 \\
\hline Vanillic acid & 0.98 & 0.81 & 0.85 & 0.816 \\
\hline Caffeic acid & 1.50 & 1.24 & 1.34 & 1.20 \\
\hline Syringic acid & 0.69 & n.d & n.d & 0.60 \\
\hline$p$-Coumaric acid & 0.60 & 0.55 & 0.59 & 0.55 \\
\hline Sinamik acid & 0.57 & 0.55 & 0.63 & 0.52 \\
\hline Ferulic acid & 0.96 & 0.81 & 0.84 & 0.80 \\
\hline Rutin & 2.93 & 0.61 & 1.44 & 0.53 \\
\hline Catechin & 2.35 & 1.71 & 1.41 & 1.51 \\
\hline Epicatechin & 6.39 & n.d & 4.68 & n.d \\
\hline Luteolin & n.d & n.d & n.d & n.d \\
\hline
\end{tabular}

Means \pm standard deviations;Different letters (a-d) in the same lines are significantly different at the $5 \%$ level $(p<0.05) *$ The experiments were performed in triplicate. n.d: Not Detected.

Honeys' free radical scavenging capacities were tested using commercial DPPH assay and values were expressed as $\mathrm{SC}_{50}$. A high DPPH value indicates low radial scavenging ability. The lowest $\mathrm{SC}_{50}$ value was in pure honey, followed by sucrose syrup (Table 3). As with FRAP activity, the lowest DPPH scavenging property was determined in HFCS honey.

Honeys' phenolic compounds were analyzed using HPLC-UV, and the resulting data are summarized in Table 3. Thirteen different standards (phenolic compounds) were used in the analysis. While lutein was beneath detectable limits in all specimens from all honeys, the other standards were detected in honeys at varying levels. With the exception of protocatechuic acid and lutein, all the standard phenolic compounds investigated were present at higher concentrations in the pure honey compared to the adulterated honeys. No significant findings that might reveal adulteration on the basis of phenolic compounds were identified, but adulteration with sugar syrup was observed to lead to a decrease or complete disappearance of phenolic compounds in honey. This increase was also cause a decrease in antioxidant capacity as well as other biological effects on the human such as anti-microbial, anti-viral, anti-inflammatory, and anti-tumoral activities of the adulterated honeys. In conclusion, adulterated honeys will have lower antioxidant capacities than those of pure honeys.

In the differentiation of adulteration in honeys produced by bees fed on various sugar honeys, $\delta^{13} \mathrm{C}$ isotope and $\mathrm{C}_{4} \%$ values are differentiating parameters for sugar cane honeys. The positive optical rotation angles of the adulterated honeys 
produced by bees fed on high fructose content syrup emerged as a significant distinguishing parameter in this study. Diastase activity was observed to play an important role in the quality of honey, with the exception of freshness. Proline values are an important parameter in determining the purity of honey, and better quality honeys can be obtained by raising the proline values in the honey codices. Adulterated honeys produced with sucrose are closer to the pure honeys in terms of both physicochemical properties and other biological characteristics. Total phenolic content also emerged as an important marker in the detection of honey adulteration and as a value requiring measurement in classic honey analyses.

\section{ACKNOWLEDGEMENTS}

This project was founded by Karadeniz Technique University (KTUBAP-9701-2013) and Turkish Ministry of Food and Agriculture (TAGEM-AR-GE/15). The authors are also grateful to Union of Trabzon Beekepers (TRAYBIR) and Zekeriya AYDIN who is an experienced beekeepers.

\section{CONFLICT OF INTERESTS}

The authors declare that they have no conflict of interests.

\section{References}

1. M. Tosun, Detection of adulteration in honey samples added various sugar syrup with ${ }^{13} \mathrm{C} /{ }^{12} \mathrm{C}$ isotope ratio analysis method, Food Chem., 138 (2013) 1629-1632.

2. A. Güler, H. Kocaokutgen, A.V. Garipoglu, H. Onder, D. Ekinci, Detection of adulterated honey produced by honeybee (Apis mellifera L.) colonies fed with different levels of commercial industrial sugar (C3 and $\mathrm{C} 4$ plants) syrups by the carbon isotope ratio analysis, Food Chem., 155 (2014) 155-160.

3. Can, O. Yildiz, H. Sahin, E.A. Turumtay, S. Silici, S. Kolayli, An investigation of Turkish honeys: Their pyhysico-chemical properties, antioxidant capacities and phenolic profiles, Food Chem., 180 (2015) 133-141.

4. I. Jasicka-Misiak, A. Poliwoda, M. Deren, P. Kafarski, Phenolic compounds and abscisic acid as potential markers for the floral origin of two Polish unifloral honeys, Food Chem., 131 (2012) 1149-1156.

5. E. Anklam, A review of the analytical methods to determine the geographical and botanical origin of honey, Food Chem., 63 (1998) 549-562.

6. Codex standard 12-1981 (Rev. 2-2001), Revised codex standard for honey, (Formerly Codex Stan-12-1987) (2001). Rome: FAO; WHO.

7. S. Bogdanov, C. Lullmann, P. martin, W.V.D. Ohe, H. Russmann, G.Vorwohl, Honey quality and international regulatory standards (Review by the International Honey Commission), Swiss Bee Res. Centre, (2005).

8. S. Cavrar, O. Yildiz, H. Sahin, F. Karahalil, S. Kolayli, Comparison of Physical and biochemical characteristics of different quality of Turkish honey. Uludag Bee J., 49 (2013) 55-62.
9. AOAC official method 991.41. C4 plant sugars in honey. AOAC Official Methods of Analysis Sugars and Sugar Products; AOAC: Arlington, VA, Chap., (44) (1995) 2931.

10. AOAC official method 998.12. C-4 plant sugars in honey. International standard stable carbon isotope ratio method. Int. Gaithersburg MD (USA), Chap. (2005) 44: 27.

11. S. Bogdanov, P. Martin, C. Lullmann, R. Borneck, C. Flamini, M. Morlot, J. Heretier, G. Vorwohl, H. Russmann, L. Persano-Oddo, A.G. Sabatini, G. Marcazzan, L. Marioleas, P. Tsigouri, K. Kerkvliet, J. Ortiz, T. Andivanov, Harmonised methods of the European honey commission, Apidologie, extra issue, (1997) 1-59.

12. S.Ouchemoukh, H. Louaileche, P.Schweizer, Physico chemical characteristics and pollen spectrum of some Algerian honey, Food Contr., 18 (2007) 52-58.

13. K.H. Kim, R. Tsao, R.Yang, S.W. Cui, Phenolic acid profiles and antioxidant activities of wheat bran extracts and the effect of hydrolysis conditions, Food Chem., 95 (2006) 466-473.

14. A. De Villiers, F. Lynen, A. Crouch, P. Sandra, Development of a solid phase extraction procedure for the simultaneous determination of polyphenols, organic acids and sugars in wine, Chromatography, 59 (2004) 403-409.

15. V.L. Singleton, R. Orthofer, R.M. Lamuela-raventós, Analysis of total phenols and other oxidation substrates and antioxidants by means of folinciocalteu reagent, Methods Enzymol., 299 (1999) 152178.

16. I.F.F. Benzie, J.J. Strain, Ferric Reducing/Antioxidant Power Assay: Direct measure of total antioxidant activity of biological fluids and modified version for simultaneous measurement of total antioxidant power and ascorbic acid concentration, Methods Enzymol., 299 (1999) 15-27.

17. P. Molyneux, The use of the stable free radical diphenylpicrylhyrazyl (DPPH) for estimating antioxidant activity, Songklanakarin J. Sci. Technol., 26 (2004) 211-221.

18. G.J. Padovan, L.P. Rodriquez, I.A. Leme, D. Jong David, J.S. Marchini, Presence of C 4 sugars in honey samples detected by the carbon isotope ratio measured by IRMS, Eur. J. Anal. Chem., 2 (2007) 134-141.

19. S. Ouchemoukh, N. Amessis-Ouchemoukh, M. GómezRomero, F. Aboud, A. Giuseppe, A. FernándezGutiérrez, A. Segura-Carretero, Characterisation of phenolic compounds in Algerian honeys by RPHPLC coupled to electrospray time-of-flight mass spectrometry, LWT-Food Scie Technol., (2016) doi. org/10.1016/j.Iwt.2016.11.084.

20. F. Tezcan, S. Kolayli, H. Sahin, E. Ulusoy, B.F. Erim, Evaluation of organic acid, saccharide composition and antioxidant properties of some authentic Turkish honeys, J. Food Nut. Res., 50 (2011) 33-40.

21. C. Cimpoiu, A. Hosu, V. Miclaus, A. Puscas, Determination of the floral origin of some Romanian honeys on the basis of physical and biochemical properties, Spectrochimica Acta Part A, 100 (2013) 149-154.

22. M. Küçük, S. Kolayli, Ş. Karaoğlu, E. Ulusoy, C. Baltaci, F. Candan, Biological activities and chemical composition of three honeys of different types from Anatolia, Food Chem., 100 (2007) 526-34. 
23. M.L. AL, D. Daniel, A. Moise, O. Bobis, L. Laslo, S Bogdanov, Physico-chemical and bioactive properties of different floral origin honeys from Romania, Food Chem., 112 (2009) 863-867.

24. M.S. Finola, M.C. Lasagno, J.M. Marioli, Microbiological and chemical characterization of honeys from central Argentina, Food Chem., 100 (2007) 1649-1653.

25. J. Ahmed, S.T. Prabhu, G.S.V. Raghavan, M. Ngadi, Physico-chemical, rheological, calorimetric and dielectric behavior of selected Indian honey, J. Food Eng., 79 (2007) 1207-1213.

26. L.M. Estevinho, X. Feas, J.A. Seijas, M.P.VazquezTato, Organic honey from Trás-Os-Montes region (Portugal): Chemical, palynological, microbiological and bioactive compounds characterization, Food Chem. Toxicol., 50 (2012) 258-264.

27. I.K. Karabagias, M.V. Vavoura, C. Nikolaou, A. Badeka, S. Kontakos, M.G. Kontaminas, Floral authentication of Greek unifloral honeys based on the combination of phenolic compounds physicochemical parameters and chemometrics, Food Res. Int., 62 (2014) 753-760.

28. F. Pasini, S. Gardini, G.L. Marcazzan, M.F. Caboni, Buckwheat honeys: Screening of composition and properties, Food Chem., 141 (2013) 2802-2811.

29. A. Belay, W.K. Solomon, G. Bultossa, N. Adgaba, S. Melaku, Physicochemical properties of the Harenna forest honey, Bale, Ethiopia, Food Chem., 141 (2013) 3386-3392.
30. R.O.R. Ribeiro, E.T. Mársico, C.S. Carneiro, M.L.G. Monteiro, C.A.C. Júnior, S. Mano, E.F.O. Jesus, Classification of Brazilian honeys by physical and chemical analytical methods and low field nuclear magnetic resonance (LF $1 \mathrm{H}$ NMR), LWT-Food Sci. Technol., 55 (2014) 90-95.

31. J. Bertoncelj, U. Dober ek, M. Jamnik, T. Golob, Evaluation of the phenolic content, antioxidant activity and colour of Slovenian honey, Food Chem., 105 (2007) 822-828.

32. J.F. Cotte, H. Casabianca, B. Giroud, M. Albert, J. Lheritier, M.F. Grenier-Loustalot, Characterization of honey amino acid profiles using high-pressure liquid chromatography to control authenticity, Anal. Bioanal. Chem., 378 (2004) 1342-1350.

33. S.Z. Gorjanovi, J.M. Alvarez-suarez, M.M. Novakovi, F.T. Pastor, L. Pezo, M. Battino, D.Z. Sužnjevi, Comparative analysis of antioxidant activity of honey of different floral sources using recently developed polarographic and various spectrophotometric assays, J. Food Comp. Anal., 30 (2013)13-18.

34. J.M. Alvarez-suarez, S. Tulipani, D. Diaz, Y. Estevez, S. Romandini, F. Giampieri, E. Damiani, P. Astolfi, S. Bompadre, M. Battino, Antioxidant and antimicrobial capacity of several monofloral cuban honeys and their correlation with color, polyphenol content and other chemical compounds, Food Chem. Toxicol., 48 (2010) 2490-2499. 